\title{
Rogowsky coil applications for power measurement under non-sinusoidal field conditions
}

Illia Diahovchenko',

Roman Mykhailyshyn²,

Dmytro Danylchenko ${ }^{3}$,

Serhii Shevchenko ${ }^{3}$

${ }^{1}$ Electrical Power Engineering Department, Sumy State University,

Sumy, Ukraine

Email ilya.dyagovchenko@gmail.com

${ }^{2}$ Department of Automation

Technological Processes and Production,

Ternopil Ivan Puluj

National Technical University,

Ternopil, Ukraine

${ }^{3}$ Electrical Power Transmission Department, National Technical University

"Kharkiv Polytechnic Institute",

Kharkiv, Ukraine
Electric energy measurement errors depend on the design and algorithms used in electricity meters, as well as on the auxiliary and embedded sensors' accuracy and bandwidth (or more precisely, maximum measurable frequency). Poor power quality may affect the electric energy meters accuracy, which will lead to the improper power accounting. In this article the applications of the Rogowsky coil sensors for electric energy measurement are studied. The advantages and the challenges of this sensor type implementation are discussed, and the operation scheme of the power meter for the separate measurement of the fundamental harmonic's electric energy and the higher harmonics electric energy is proposed. The possibility of implementation of responsibility determining methods for power quality distortion is highlighted.

Keywords: Rogowsky coil, power measurement, higher harmonics, power quality, current transducer, responsibility for power quality distortion

\section{INTRODUCTION}

The measurement of the released and supplied electricity is one of the principal tasks in the energy market. In this regard, the accuracy requirements for electric energy metering devices tend to become higher. At the present stage of the energy market development it is required to measure several power parameters simultaneously, e.g. the maximum power consumption for comparison with the claimed maximum power; the amount of electricity for a certain time period to perform multi-tariff metering; the amount of consumed energy in standard time intervals (day, week, month, year). Improving the electric energy measurement accuracy will lead to a more efficient use of equipment for power production, transmission and distribution.

To determine the amount of consumed electricity and analyze its quality parameters (for example, voltage dips and sags, harmonic spectrum), electronic meters need information about the network current and voltage levels. The accuracy of a power meter is a function of the measurement error, which depends on the current and voltage sensors' accuracy. Nowadays power meters' manufacturers use three main sensor types: resistive, current transformers, and Hall 
effect based transducers [1]. Current transducers implemented on the basis of these methods have their own errors, which manufacturers try to eliminate by design improving and utilization of alternative materials [2,3]. This allows obtaining the electricity values within sufficient accuracy for economic calculations. When primary currents are high (above $200 \mathrm{~A}$ ) three-phase digital meters are indirectly connected through the measuring current transformers (CTs). In this case, the electric energy measurement error consists of both the error of the power meter itself and the error of the CT.

Conventional inductive current and voltage transformers with a ferromagnetic core have certain disadvantages caused by the very nature of such transformers: saturation, hysteresis, residual magnetization. In addition, the transformation ratio indicated in the device's passport corresponds to the real transformation ratio only with a sinusoidal form of the measured current and may have deviations at low power quality [4]. Nonlinear coupling of the induction and magnetic field strength and the hysteresis nature of the ferromagnetic core magnetization cycle both lead to the violation of the proportion between the primary and secondary CT's current, as well as to the phase shift of the secondary CT's current relatively the primary current. These ultimately cause the appearance of angular and current measurement errors and, consequently, distort the electric energy measurement results. Thus, measuring CTs (and also voltage transformers) can become an obstacle for high-accuracy electricity measurement.

One of the alternative ways to measure current and voltage is the Rogowski coil (RC). This is an old device that has been modified and improved over a century since its definitive description in 1912, and it is still being studied for new applications. Several scientific papers are devoted to the study of RC application prospects. In [5] different methods about the Rogowski coil output integration block are discussed and various applications of the device are reviewed. In [6] the design, installation, and performance basics of the RC are presented and the study of low-frequency distortion of wide pulsed current measurement is described. The article [7] investigates the measurement uncertainty associated with the on-site use of a flexible and openable Rogowski coil. And the calibration approach of Rogowski coils with an integrator for current measurement at mains frequency is demonstrated in [8]. Previous studies have shown that the $\mathrm{RC}$ can be a good choice when creating measurement systems for power networks, because it provides ease of use for most basic measuring circuits and meets the requirements for both the measurement range and accuracy. Moreover, miniature current transducers based on the Rogowsky coil have been created. They meet the Class 0.2 percent accuracy limits for currents from $0.1 \mathrm{~A}$ to $200 \mathrm{~A}$ and above for IEC 60044 and ANSI C12.20 [9]. Such devices may well replace the traditional current sensors used in electronic power meters. The aim of the presented work is to validate the expediency of the RC applications in commercial power meters, which operate in electric networks with power quality distortions.

The reminder of this paper is organized as follows. The next section states the advantages, illustrates the measurement problems and summarizes their solutions related to the RC. Further, the approach of the RC application for improving the accuracy of electric energy measurements and separate power accounting by the fundamental harmonic and higher harmonics is proposed. And finally the conclusions are stated.

\section{ROGOWSKI COIL APPLICATIONS FOR VOLTAGE AND CURRENT MEASUREMENTS}

\section{Advantages of RC transducer}

The Rogowski coil is a toroidal coil located around the primary wire, similarly as the secondary winding of a conventional current transformer, but without a ferromagnetic core (Fig. 1). The output of the RC was insufficient in conventional measuring methods, which was the main limit in past decades. However, nowadays by developments of microprocessor-based measurement devices, the RC is more suitable for various applications.

The RC is a proper choice for measuring systems in power networks, since it provides ease of use for most basic measuring circuits and meets the requirements for both the measurement range and accuracy. Its main advantages are [5]: 


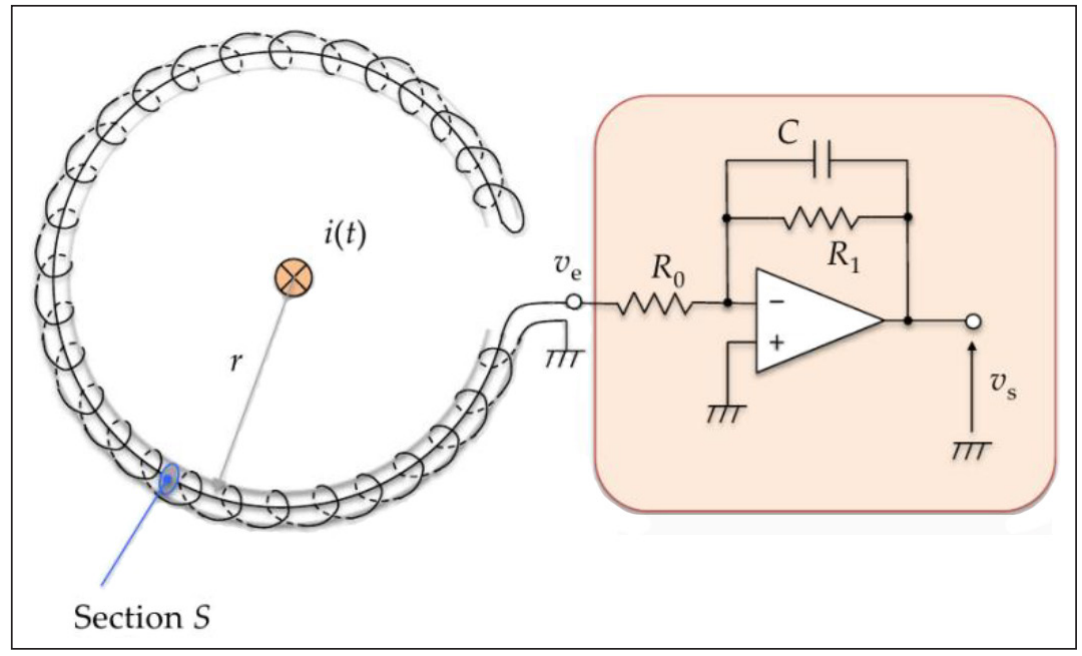

Fig. 1. Rogowski coil setup and its 0pAmp-based integrator

- withstands large overloads without damage;

- measures currents in an extensive range, without saturation;

- wide bandwidth (range from $0.1 \mathrm{~Hz}$ to $1 \mathrm{GHz}$ );

- low cost;

- temperature independent;

- excellent transient response;

- does not have non-linear elements (linearity of the measured signals is guaranteed throughout the whole range);

- ease of installation, due to light weight and flexibility;

- no power consumption from the main circuit;

- safety (electrically isolated from the main circuit).

\section{Challenges for accurate measurements}

The sensor's output voltage signal is proportional to the current derivative [10]:

$$
u=-M \frac{d i}{d t},
$$

where $M$ is the mutual inductance between the primary conductor and the coil.

The current value can be calculated or obtained by hardware using an analogue integrator, such as operational amplifier (OpAmp), which is framed in Fig. 1 on the right, and its frequency characteristic is shown in Fig. 2.

In the bandwidth between $f_{1}$ and $f_{2}$ the circuit acts as an integrator. The mentioned frequencies are calculated as follows [5]:

$$
f_{1}=\frac{1}{2 \pi R_{0} C}, f_{2}=\frac{1}{2 \pi R_{1} C} .
$$

The challenge of this measurement method is to ensure sufficient accuracy, since the calculation is based on the assumption of perfect symmetry of the coil relative to the current conductor and the ideal geometry of the coil itself. Only under these conditions the inductance $M$ remains constant. However, in practice, this is difficult to achieve because of the following factors:

- coil winding is not regular and uniform along the entire length;

- the cross-section is inhomogeneous along the length of the coil.

Such asymmetries leads to a change in the inductance coefficient $M$ relative to the conductor. Thus, the Rogowsky coil performance is

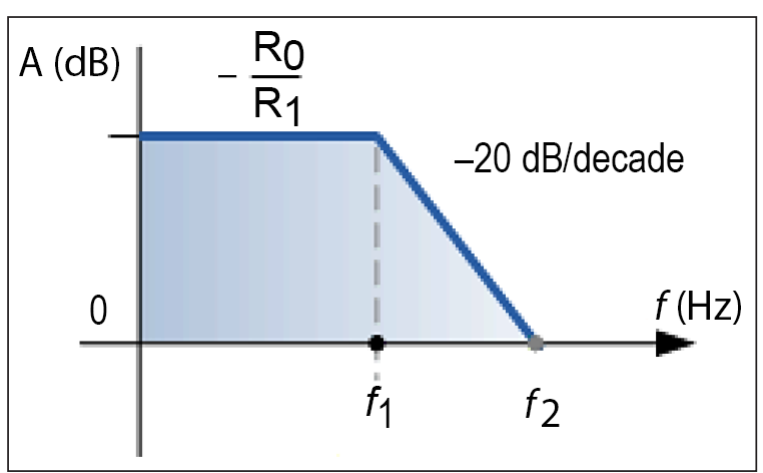

Fig. 2. Frequency characteristic of the OpAmp amplifier 
generally determined by the error associated with the conductor position inside the measuring loop, which is clearly shown in [7]. In addition, a good sensor must remain insensitive to all other external conductors located outside the measuring circuit. If the sensor's current loop design fails, the errors related to the interference sensitivity and conductor positioning inside the sensor loop are observed. This is a result of Ampere's theorem, according to which any error associated with any form of asymmetry is valid both inside and outside the loop.

\section{Independence from higher harmonics}

Referring to the Ampere's law, the relation between the current flowing through the RC and the intuitive magnetic, along the axis of the torus, is as follows:

$$
i=\frac{1}{\mu_{0}} \oint_{L} b d l,
$$

where $d l$ is an elementary element of length along the loop, $b$ is the instantaneous value of the magnetic field, $\mu_{0}$ is the magnetic constant, $L$ is the middle line of the $\mathrm{RC}$ measuring winding, i.e. the integration circuit.

Given that

$$
b=\mu_{0} h,
$$

the relationship between the magnetic field strength $h$ and the measured current can be written as

$$
i=\oint_{L} h d l \text {. }
$$

Use the ratio of the magnetic flux:

$$
\Phi=b S=\mu_{0} h S,
$$

where $S$ is the area of the measuring winding's coil.

Multiply both parts of (5) by $\mu_{0} S$ and differentiate by time:

$$
\mu_{0} \frac{d i}{d t} S=\oint_{L} e d l
$$

where $e=\frac{d\left(\mu_{0} h S\right)}{d t}$ is the instantaneous EMF value of a single $\mathrm{RC}$ winding turn.
In deriving equation (7), it was assumed that the vectors $h$ and $d l$ are parallel to each other at all points of the integration contour $L$.

The instantaneous EMF value of the entire RC measuring winding with $N$ turns:

$$
E(t)=e N
$$

Taking the initial phase of the measured current as zero and using the law of electromagnetic induction, it is easy to obtain the following equation [11]:

$$
E(t)=C \omega I_{m} \sin \left(\omega t-\frac{\pi}{2}\right),
$$

where $\omega$ is the angular frequency, $C=\frac{\mu_{0} S N}{L}$ is the design parameter of the transducer.

Electronically obtain a voltage proportional to the instantaneous value of the measured current

$$
u_{l c}=C I_{m} \sin \omega t
$$

To do this, divide $\mathrm{E}(t)$ by $\omega$ and perform a positive $\pi / 2$ phase shift.

The voltage $u_{l c}$ proportional to the load's current is applied to the first input of the digital power meter. To the second input of the power meter, the load's voltage $u_{l v}$ is applied:

$$
u_{l v}=U_{m} \sin (\omega t+\varphi) \text {. }
$$

The division of $E(t)$ by $\omega$ gives another advantage - eliminates the result dependence on the supply current frequency, which reduces the measurement error.

The power meter records the amount of consumed electric energy over time. One of the common algorithms for real energy accounting is expressed by equation [12]:

$$
W_{P}=\Sigma U_{n} \cdot I_{n} \cdot \cos \varphi_{n} \cdot t=\sum_{n=0}^{40} P_{n} \cdot t,
$$

where $U_{n}, I_{n}, \varphi_{n}$ and $P_{n}$ are the voltage, current, phase-shift angle, and active power of the $n$-th harmonic, respectively; $t$ is the current time.

\section{Findings}

Since higher harmonics (HH) do not affect the accuracy of the Rogowski coil, the accuracy of 
electricity metering will depend only on the digital signal processing error. Therefore, a properly designed RC-based transducers may be considered a preferred choice for commercial power measurement, compared to CT and Hall sensors. Besides, it should be noted that with the same spectrum of voltage and current frequencies, different power meter samples can show significantly different results, as shown in [13].

\section{RC APPLICATION FOR SEPARATE MEASUREMENT OF FUNDAMENTAL HARMONIC'S POWER AND HH POWER}

Power quality in Ukrainian grids is low and will remain poor in the near future. The reduction of power quality is mainly caused by the industrial consumers, who use voltage converters, arc steel furnaces, pulsed power supplies, as well as installations with asymmetric and shock loads. This leads to distortion of voltage and current curves, causes additional errors in the electricity metering system and significant economic losses. A certain share of $\mathrm{HH}$ is created by power plants themselves, since it is technically impossible to create an industrial generator that would generate a pure sine. At the same time, consumers with predominantly linear volt-ampere characteristic, who do not generate $\mathrm{HH}$ to the grid, are affected by supply voltage waveform distortion.

To compensate the losses caused by the non-sinusoidal voltage, it is possible to develop a power meter for the separate measure- ment of the fundamental harmonic's electric energy and the higher harmonics electric energy. Such metering device should be bi-directional and measure electric energy flowing in two directions. The positive energy values correspond to the case when the fundamental frequency energy and $\mathrm{HH}$ energy come from the mains supply to a consumer and, conversely, the negative values correspond to the case when the industrial frequency energy and $\mathrm{HH}$ energy head from a consumer to the network. In more detail the mechanisms of such power measurement are described in [14]. The operation principle of a suchlike meter can be defined by the following equation:

$$
\begin{aligned}
& W_{P}=U_{1} \cdot I_{1} \cdot \cos \varphi_{1} \cdot t-\sum_{n=2}^{k} U_{n} \cdot I_{n . g e n} \cdot \cos \varphi_{n . g e n} \cdot t+ \\
& +\sum_{n=2}^{k} U_{n} \cdot I_{n . l o a d} \cdot \cos \varphi_{n l o a d} \cdot t=W_{1}-W_{n . g e n}+W_{n . l o a d,}
\end{aligned}
$$

where $W_{1}$ is the electric energy of the industrial frequency $(50$ or $60 \mathrm{~Hz}) ; W_{n . g e n}, I_{n . g e n}, \varphi_{\text {n.gen }}$ are the electric energy, current, and phase-shift angle of the $n$-th harmonic, which flows from the main grid to the load, respectively; $W_{\text {n.load }} I_{n \text {.load }} \varphi_{\text {n.load }}$ are the electric energy, current, and phase-shift angle of the $n$-th harmonic, which is generated by nonlinear loads and flows to the mains, respectively. In case of a three-phase meter, calculations by equation (13) must be performed for each phase separately and then summed up.

The operation scheme of the described power meter is shown in Fig. 3.

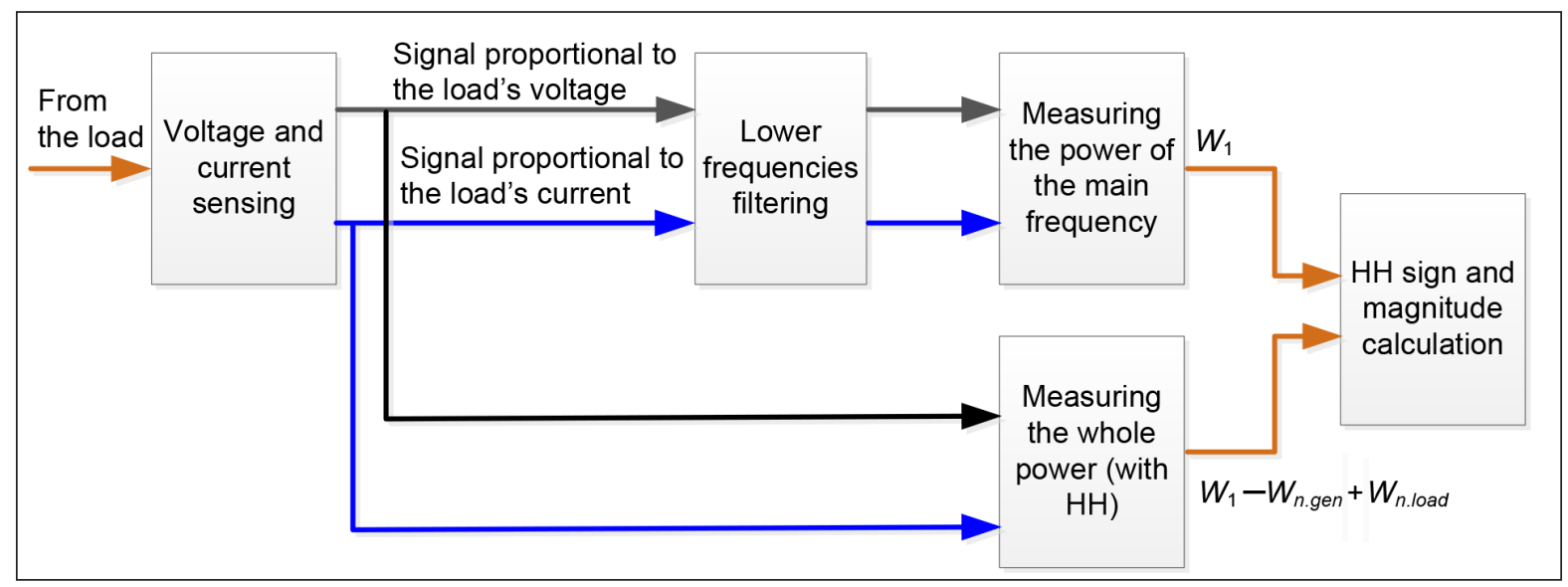

Fig. 3. The operation scheme of the power meter for the separate measurement of the fundamental harmonic's electric energy and the higher harmonics electric energy 
In the first step RC senses voltage and current signals. Then these signals simultaneously go on two ways:

1) through a low frequency filter, which isolates fundamental harmonic and cuts off $\mathrm{HH}$, to a measuring unit which measures electric energy according to equation (12);

2) directly to a measuring unit, which operates according to equation (13).

Then the outputs of two measuring units are compared and the $\mathrm{HH}$ sign and magnitude are determined.

The power meter operating on the model in Fig. 3 will allow to implement a mechanism for sharing the responsibility between power suppliers and consumers for exceeding the permissible $\mathrm{HH}$ deviation ranges. The issue of implementation of responsibility determining methods for severe power quality distortion was considered in the paper [15]. However, a solution for the case of supply voltage distortion was not found.

Application of the Rogowsky coil (or compact RC-based sensors) can contribute to the solution of the issue of implementation of a mechanism for sharing the responsibility between power suppliers and consumers for exceeding the permissible $\mathrm{HH}$ deviation ranges, since the high-accurate values, proportional to the load's current and voltage, can be easily obtained. The electric energy meter, which is able to measure the energy of the main frequency and higher harmonics separately, can be elaborated on the basis of the operation scheme (Fig. 3). The block diagram considered in [11] can be exploited to develop an alike power measuring devise.

\section{CONCLUSIONS}

Rogowski-coil transducers can offer a very useful contribution to the measuring of electric currents and voltages under non-sinusoidal field conditions. A wider understanding of the RC's nature and what it can do is obviously essential if this sensor's full potential is to be exploited for power and electric energy measurement. In this paper it is shown that the Rogowsky coil is not dependent on the supply current frequency, which reduces the measurement error. The advantages and the challenges of this sen- sor type are illustrated. The operation scheme of the power meter for the separate measurement of the fundamental harmonic's electric energy and the higher harmonics electric energy is proposed. Implementation of the proposed meter can allow to employ a mechanism for sharing responsibility between power suppliers and power consumers for exceeding the permissible $\mathrm{HH}$ deviation ranges and, through this, compensate the losses caused by the non-sinusoidal voltage.

Received 15 December 2018 Accepted 14 March 2019

\section{References}

1. Volokhin V., Diahovchenko I. Peculiarities of current sensors used in contemporary electric energy metering devices. Energetika. 2017. Vol. 63. No. 1. P. 8-15.

2. Volokhin V. V., Diahovchenko I. M. The use of nanocrystalline and amorphous materials for electric energy metering improvement and reducing the effects of external magnetic fields. Proceedings of the 6th International Conference Nanomaterials: Applications and Properties, NAP 2016, Lviv, Ukraine. P. 02NEA03-1O2NEA03-3.

3. Volokhin V. V., Diahovchenko I. M., Derevyanko B. V. Prospects of nanomaterials use in current and voltage hall sensors to improve the measurements accuracy and reduce the external impacts. Proceedings of the 2017 IEEE 7th International Conference on Nanomaterials: Applications and Properties, NAP 2017, Zatoka, Ukraine. P. 03NEA08-1-O3NEA08-5.

4. Shidlovskiy A. K., Zharkin A. F. Vyisshie garmoniki $v$ nizkovoltnyih elektricheskih setyah. Kiev: Naukova dumka, 2005.

5. Samimi M. H., Mahari A., Farahnakian M. A., Mohseni H. The Rogowski Coil principles and applications: A review. IEEE Sensors Journal. 2015. P. 1-8.

6. Liu Y., Lin F., Zhang Q., Zhong H. Design and construction of a Rogowski Coil for measuring wide pulsed current. IEEE Sensors Journal. 2011. P. 123-130.

7. Chiampi M., Crotti G., Morando A. Evaluation of flexible rogowski coil performances in power 
frequency applications. IEEE Transactions on Instrumentation and Measurement. 2011. P. 854-862.

8. Draxler K., Styblikova R., Hlavacek J., Prochazka R. Calibration of Rogowski coils with an integrator at high currents. IEEE Transactions on Instrumentation and Measurement. 2011. P. 2434-2438.

9. Pulse Electronics Product Overview. Sidewinder AC Current Sensor.

10. Ward D. A., Exon J. L. T. Using Rogowski coils for transient current measurements. Engineering Science and Education Journal. 1993. P. 105-113.

11. Suslov K. V., Solonina N. N., Smirnov A. S. Using the Rogowski coil to improve the accuracy and quality of electrical energy. 6th International Scientific Symposium ELECTROENERGETIKA 2011, Stara Lesna, Slovakia. P. 364-368.

12. Volokhin V., Diahovchenko I., Kurochkina V., Kanálik M. The influence of nonsinusoidal supply voltage on the amount of power consumption and electricity meter readings. Energetika. Vol. 63. No. 1. 2017. P. 1-7.

13. Diahovchenko I., Volokhin V., Kurochkina V., Špes M., Kosterec M. Effect of harmonic distortion on electric energy meters of different metrological principles. Frontiers in Energy. 2018.

14. Morva G., Volokhin V., Diahovchenko I., Čonka Z. Analysis of the impact of nonlinear distortion in voltage and current curves on the errors of electric energy metering devices. 2017 IEEE 1st Ukraine Conference on Electrical and
Computer Engineering, UKRCON, 2017, Kiev, Ukraine. P. 528-533.

15. Grib O. G., Senderovich G. A., Scherbakova P. G. Aktualnyie zadachi opredeleniya dolevogo uchastiya $\mathrm{v}$ otvetstvennosti za narushenie kachestva elektricheskoy energii. Naukovi pratsi DonNTU. Vol. 1. No. 14. 2013. P. 77-82.

Illia Diahovchenko, Roman Mykhailyshyn, Dmytro Danylchenko, Serhii Shevchenko

\section{ROGOVSKIO RITĖS TAIKYMAI ELEKTROS ENERGIJAI MATUOTI NESINUSOIDINIO LAUKO SĄLYGOMIS}

\section{Santrauka}

Elektros energijos apskaitos paklaidos priklauso nuo skaitiklių konstrukcijos ir įdiegtų algoritmų, įmontuotų ir pagalbinių jutiklių tikslumo, taip pat matavimų diapazono (pirmiausia nuo viršutinès dažnio matavimo ribos). Prasta energijos kokybè mažina apskaitos tikslumą. Straipsnyje nagrinejjamas Rogovskio ritès tipo jutiklių taikymas elektros energijos matavimams. Aptariami minètų jutiklių pranašumai ir trūkumai. Teikiama šiais jutikliais grindžiama elektros energijos harmonikų matavimo schema elektros skaitikliams. Pagal ją pagrindinè ir aukštesnès harmonikos matuojamos atskirai. Pabrèžiama, kaip svarbu taikyti atsakomybès nustatymo metodus už veiksmus, turinčius itakos energijos kokybei.

Raktažodžiai: Rogovskio ritė, energijos matavimai, aukštesnès harmonikos, energijos kokybe், srovès daviklis 